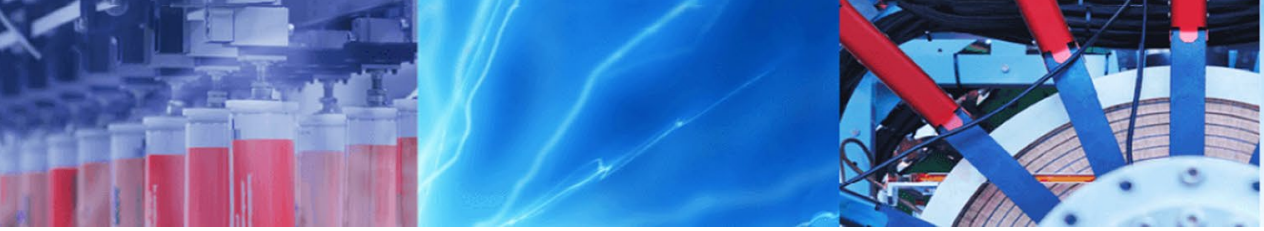

Research Article

\title{
Alleviation of heavy metal stress in Nyctanthes arbor-tristis under the treatment of lead
}

\author{
Ajay Kumar ${ }^{1} \cdot$ Shubhi Mishra ${ }^{1} \cdot$ Meetu Chaudhary ${ }^{1}$
}

(c) Springer Nature Switzerland AG 2019

\begin{abstract}
The plant release or maintain the level of antioxidants in their response toward heavy metal toxicity which is also a part of plant defense mechanism. Apart from this, the presence of antioxidants and antiradical properties is the principle reason for the popularity of medicinal plants. Nyctanthes arbor-tristis or Parijat is one of them. In the present study, various morphological, biochemical and physiochemical parameters of Parijat were analyzed under the condition of lead stress of varying strengths. An increment was recorded in the concentration of superoxide dismutase (SOD), lipid peroxidase, guaiacol peroxidase and non-protein thiols content with the increasing concentration of lead stress, indicating that they have an essential role in coping the heavy metal stress, whereas the exogenous lead stress treatment imparted a negative effect on the content of chlorophyll and protein in the plant. It can be concluded through the present study that the plant $N$. arbor-tristis can be potentially used as phytoremediator for heavy metal stress due to its hyperaccumulation and antioxidant properties.
\end{abstract}

Keywords Parijat · Antioxidant · Hyperaccumulation $\cdot$ Phytoremediator $\cdot$ Remediation

\section{Introduction}

Metal ions have important role as trace elements in many physiological, biochemical activities of both flora and fauna, whereas they are also significant environmental pollutants [1]. Lead $(\mathrm{Pb})$ is one of those naturally occurring metals. Its concentration is increasing in the environment due to the human anthropogenic activities such as mining, coal burning, industrial, agricultural and domestic uses [2]. Human is exposed to this lead contamination via inhalation of aerosols, paint, etc. One of the most important sources of lead ingestion is lead contaminated food because of its increasing concentration in our agricultural fields [3]. According to Environmental Protection Agency (EPA), lead is considered as a carcinogen. Not only humans, plants too are affected by the contamination of heavy metals which accumulate in plants due to its higher exogenous level that results in dysfunction of several physiological and biochemical activities of plant such as chlorophyll synthesis, plant growth and seed germination [4]. Contrary to this, plants also play an important role in alleviating these imperishable heavy metal pollutants. Use of plants and other living organisms for coping up with heavy metal stress is widely known as bioremediation.

Plants are known as solar pumps. Plants have a tendency to absorb micronutrients from soil for their growth and have the ability to concentrate and accumulate these heavy metals from environment in an eco-friendly manner [5]. Some of the plants possess very high tendency of accumulation which led to the absorption of significant amounts of essential elements as well as non-essential metals such as lead. An increased lead $(\mathrm{Pb})$ level results

Ajay Kumar and Shubhi Mishra contributed equally to this work.

Shubhi Mishra, shubhimishra970@gmail.com | 'Saaii College of Medical Science and Technology Affiliated by CSJMU, Kanpur, Uttar Pradesh, India.

SN Applied Sciences (2019) 1:143 | https://doi.org/10.1007/s42452-018-0150-4 
in the retardation of enzyme activities, water imbalance, alterations in membrane permeability as well as it also disturbs mineral nutrition [4].

High $\mathrm{Pb}$ concentration induces oxidative stress due to increase in reactive oxygen species (ROS) in plants. Superoxide, peroxide, singlet oxygen and the hydroxyl radical are some of ROS compounds [6]. They may also cause protein, membrane as well as DNA damage which may even cause cell death if present in excess amount [7]. This oxidative damage is an especially critical etiological factor implicated in several chronic human diseases. Same as human, plants also experience oxidative stress when exposed to heavy metal stresses [7]. Antioxidant enzymes act as defense system of plants in order to protect them from the damage produced by oxygen-derived radical including oxidative stress induced by heavy metals. These enzymes have the ability to scavenge ROS and prevent themselves from oxidative damage. This system is composed of antioxidant enzymes: ascorbate peroxidase (APOX), superoxide dismutase (SOD), catalase (CAT) and non-enzymatic compounds (ascorbic acid, glutathione, carotenoids, tocopherols) [8]. The presence of heavy metals, such as lead, imparts their toxic effects on plants, animals and other living organisms. Keeping the above points in the mind, the present research is carried out to increase the understanding of heavy metal toxicity on plants and allied areas to maintain the ecological harmony of the globe. In this study, the exogenous lead treatment was given to $N$. arbortristis and its effects on plant were observed. The increase in the antioxidant compounds and decay in the morphological and physiochemical parameters of the plant were measured as the indicator of heavy metal toxicity.

\section{Materials and methods}

The present study was carried out in the research laboratory of Saaii College of Medical Science and Technology, Kanpur. For this experiment, eighteen pots were taken and each was filled with approximately $2 \mathrm{~kg}$ of soil. The plants were collected from a nursery of Kanpur and grown with the five different concentrations of lead nitrate, i.e., 50, $100,150,200$ and $250 \mathrm{mg} / \mathrm{kg}$ of soil which were labeled as $A, B, C, D$ and $E$, respectively. Only one plant was planted in each pot. Three replicates, namely, 1, 2 and 3, were taken for each of the treatment along with a control $X$ which was without any treatment. After growing the plants in the greenhouse for 3 months, following assays were performed. For analyzing the effect of lead toxicity, morphological, biochemical and physiochemical parameters were measured. The plant height was measured as morphological parameters. Antioxidant assays, superoxide dismutase (SOD), non-protein thiols (NPTs), lipid peroxidase (LPX) and guaiacol peroxidase (GPX) were measured as biochemical parameters, and protein and chlorophyll contents were estimated as physiochemical parameters.

\subsection{Measurement of plant height}

The height of the plant $N$. arbor-tristis was measured after 90 days of the lead treatment. The measurement was taken for each of the replicates of stress-treated plant along with their control.

\subsection{Chlorophyll content estimation}

The content of the chlorophyll in the sample was estimated with standard protocol [9] with some modifications. $0.5 \mathrm{~g}$ of leaves was ground with $80 \%$ acetone. The mixture was later centrifuged at $5000 \mathrm{rpm}$ for $5 \mathrm{~min}$, and supernatant was transferred to $100-\mathrm{mL}$ volumetric flask. The procedure was repeated until the residue became brown. The volume was maintained up to $20 \mathrm{~mL}$ with $80 \%$ acetone. The absorbance of the solution was read at 645 and $663 \mathrm{~nm}$.

\subsection{Protein content estimation}

Protein content estimation was done by the method given previously [10] with slight modifications. $1 \mathrm{~g}$ of leaves was homogenized using $5 \mathrm{~mL}$ distilled water. The resultant was centrifuged at $5000 \mathrm{rpm}$ for $10 \mathrm{~min}$, and the supernatant was transferred and used for protein estimation. $5 \mathrm{~mL}$ of alkaline copper solution was added to $1 \mathrm{~mL}$ of supernatant. The solution was mixed well and incubated at room temperature for $10 \mathrm{~min}$. Later, $0.25 \mathrm{~mL}$ of Folin-Ciocalteu reagent ( $F C R$ ) was added in the mixture and was again incubated in dark for $30 \mathrm{~min}$ and the absorbance was measured at $660 \mathrm{~nm}$ against blank. The standards were prepared using different concentrations of bovine serum albumin (BSA). 0.2, 0.4, 0.6, 0.8 and $1 \mathrm{~mL}$ concentration of BSA was taken in the test tubes, and 0.8, 0.6, 0.4 and $0.2 \mathrm{~mL}$ distilled water was added into it, respectively. After that, $5 \mathrm{~mL}$ of alkaline copper sulfate was added to each tube and mixed well. The prepared mixture of BSA was also incubated at room temperature for $10 \mathrm{~min}$. Finally, $0.12 \mathrm{~mL}$ of FCR was added and incubated in dark for $30 \mathrm{~min}$. After incubation, the absorbance was measured through spectrophotometry at $660 \mathrm{~nm}$.

\subsection{Assay of superoxide dismutase (SOD)}

SOD activity was assayed through the modified previously given method [11] which was followed by the photoreduction of nitro-blue tetrazolium (NBT). In this method, $0.2 \mathrm{~g}$ of leaves were ground with $3 \mathrm{~mL}$ lead sulfide (PbS) 
and centrifuged at $4{ }^{\circ} \mathrm{C}$ for $20 \mathrm{~min}$ at $3000 \mathrm{rpm}$. The supernatant was removed, which was used as enzyme extract in the reaction. Then, $6 \mathrm{~mL}$ of reaction mixture was prepared which contained $0.2 \mathrm{~mL}$ of enzyme extract, $0.4 \mathrm{~mL}$ of methionine, $0.2 \mathrm{~mL}$ of NBT, $0.2 \mathrm{~mL}$ of ethylene diamine tetra-acetic acid (EDTA), $0.2 \mathrm{~mL}$ of $\mathrm{Na}_{2} \mathrm{CO}_{3}$ and $4.8 \mathrm{~mL}$ of distilled water. The reaction of the reaction mixture was started by adding $2.0 \mu \mathrm{M}$ riboflavin and placing the tubes in $1500 \mathrm{~mm}$ fluorescent lamp for $15 \mathrm{~min}$. A complete reaction mixture without enzyme extract was used as control which gave maximum color. The reaction was stopped by switching off the light. A non-irradiated complete reaction mixture was used as the blank. The absorbance was read at $560 \mathrm{~nm}$, and one unit of SOD was defined as the enzyme activity that inhibited the photo-reduction of NBT to blue formazan by $50 \%$ and SOD activity of the extracts was expressed as SOD units per mg of protein.

\subsection{Assay of guaiacol peroxidase (GPX)}

Guaiacol peroxidase was estimated according to the previously described method [12]. $0.2 \mathrm{~g}$ of leaf samples were homogenized in $5 \mathrm{~mL}$ of cold $50 \mathrm{mM}$ sodium phosphate buffer ( $\mathrm{pH}$ 7.0). The homogenates were centrifuged at $22,000 \mathrm{rpm}$ for $10 \mathrm{~min}$. The enzyme extract was dialyzed for the assay. $5 \mathrm{~mL}$ of assay mixture was prepared containing $40 \mathrm{mM}$ sodium phosphate buffer ( $\mathrm{pH}$ 6.1), 2 mM hydrogen peroxide $\left(\mathrm{H}_{2} \mathrm{O}_{2}\right), 9 \mathrm{mM}$ guaiacol and $50 \mu \mathrm{l}$ enzyme extract. Increase in absorbance was measured at $420 \mathrm{~nm}$ (extinction coefficient of $26.6 \mathrm{mM}^{-1} \mathrm{~cm}^{-1}$ ) at $30 \mathrm{~s}$ intervals up to $2 \mathrm{~min}$, using a spectrophotometer. Enzyme-specific activity is expressed as $\mu \mathrm{mol}$ of $\mathrm{H}_{2} \mathrm{O}_{2}$ reduced $\mathrm{min}^{-1} \mathrm{mg}^{-1}$ protein.

\subsection{Assay of lipid peroxidase (LPX)}

The level of lipid peroxidation products was estimated following the previously given method [13]. $0.2 \mathrm{~g}$ of leaf samples were ground in $0.25 \%$ thiobarbituric acid (TBA) in $10 \%$ trichloroacetic acid (TCA) using mortar and pestle. The mixture was kept in boiling water bath for $30 \mathrm{~min}$ and then quickly cooled and centrifuged at $10,000 \mathrm{rpm}$ for $10 \mathrm{~min}$. A total of $0.25 \%$ TBA in $10 \%$ TCA served as blank. The thiobarbituric reactive substances (TBARS) thus formed were measured at $532 \mathrm{~nm}$ after adjusting for nonspecific absorbance at $600 \mathrm{~nm}$. TBARS are an index of lipid peroxidation.

\subsection{Assay of non-protein thiols (NPTs)}

The estimation of NPTs content was done by using the previously given protocol [14]. In this procedure, $0.2 \mathrm{~g}$ of leaves were homogenized in $600 \mu \mathrm{L}$ of $1 \mathrm{M} \mathrm{NaOH}$ and
$1 \mathrm{mg} \mathrm{mL}^{-1} \mathrm{NaBH}_{4}$. The homogenate was centrifuged at $13,000 \mathrm{rpm}$ for $15 \mathrm{~min}$ at $4{ }^{\circ} \mathrm{C}$. Four hundred microliters of supernatant was collected, and $66 \mu \mathrm{L}$ of $37 \% \mathrm{HCl}$ was added into it. It was again centrifuged at $13,000 \mathrm{rpm}$ for $10 \mathrm{~min}$ at $4{ }^{\circ} \mathrm{C}$. For the quantification, $200 \mu \mathrm{L}$ of the supernatant was collected and mixed with $800 \mu \mathrm{L}$ of $1 \mathrm{M} \mathrm{K}-\mathrm{Pi}$ buffer ( $\mathrm{pH} 7.5$ ) containing or not $0.6 \mathrm{mM}$ Ellman's reagent $\left\{\left[5,5^{\prime}\right.\right.$-dithiobis(2-nitrobenzoic acid); DTNB]\}. The absorbance of the samples was measured at $412 \mathrm{~nm}$.

\subsection{Statistical analysis}

The significance level of generated data was determined through $t$ test. $P<0.05$ was considered as the level of significance.

\section{Results and discussion}

Heavy metals cause multiple effects in the plant cytoplasm. Primarily, there is enhancement in the generation of ROS such as $\mathrm{O}^{2-}, \mathrm{OH}^{-}, \mathrm{H}_{2} \mathrm{O}_{2}$ and $1 \mathrm{O}_{2}$ cells. These ROS are generated directly through Haber-Weiss reactions. Their over-production may result in an indirect consequence of heavy metal toxicity [15]. The catalysis activity of functionally essential thiol(S)-groups is inactivated in enzyme due to the binding of ROS [16]. Effect of Pb contamination has been reported in several plants such as eggplant seedlings [17], capsicum [18], urad [19], mungbean [20] and wheat and spinach seedling [4] in various reports along with the reports of other heavy metal contaminants [21-23] in previous findings. This study was carried out to analyze the effect of lead contamination on the plant $N$. arbor-tristis (Parijat) which is widely known for its medicinal and antioxidant properties.

\subsection{Effect of $\mathrm{Pb}$-induced stress on plant height}

It was observed in the present study that the inhibition of plant height, a parameter of plant growth, was directly proportional to the increasing $\mathrm{Pb}$ concentration due to the excess $\mathrm{Pb}$ contamination in root environment. Under $\mathrm{Pb}$-induced stress condition, plant height was observed to be significantly affected in adverse manner as the treatment of $\mathrm{Pb}$ increased which is clearly represented in Fig. 1. The average height of the plant under controlled condition was $23 \mathrm{~cm}$. After treating the plant with $50 \mathrm{ppm}$ for 90 days, an increase of $19 \mathrm{~cm}$ was recorded in the plant height which was about $19 \%(P=0.006)$ short from the plant under controlled condition. Under the $\mathrm{Pb}$ concentration of $100 \mathrm{ppm}$, the height increased only $15 \mathrm{~cm}$ which was about $36 \%(P=0.01)$ shorter than the plant under controlled condition. After 150 ppm, 200 ppm and 250 ppm 
Fig. 1 Effect of different lead concentrations on plant height of N. arbor-tristis plants. Note: ${ }^{*}, * *, * * *$ indicate significant at $0.01<P<0.05,0.001<P<0.01$, and $0<P<0.001$, respectively

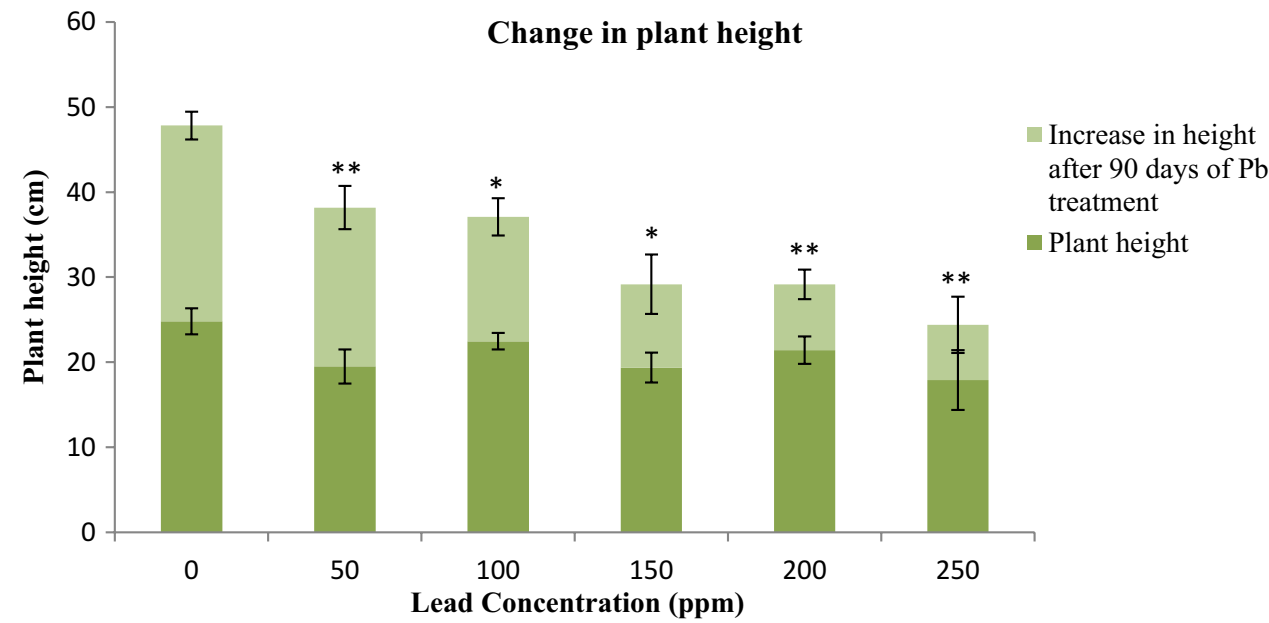

\section{Change in chlorophyll content}

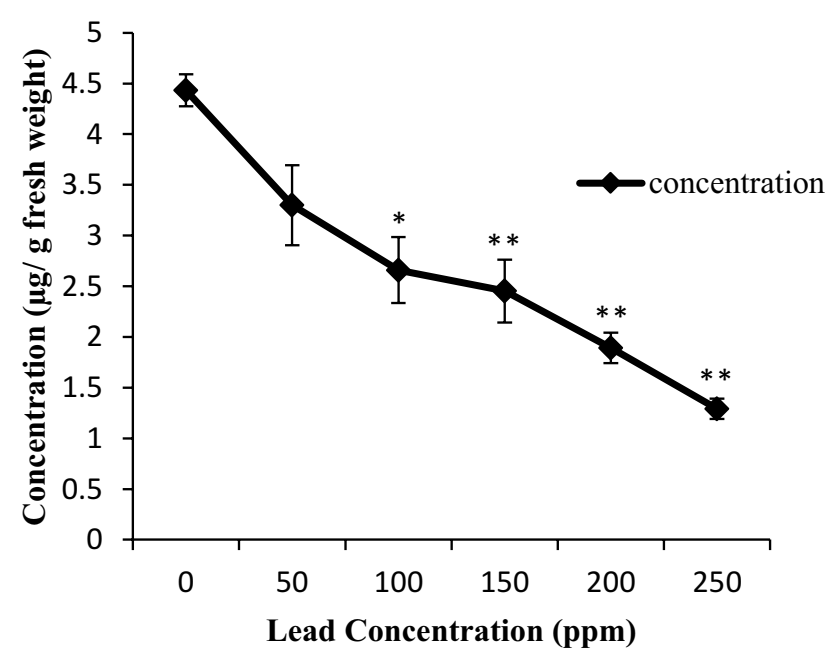

Fig. 2 Effect of different lead concentrations on chlorophyll content of N. arbor-tristis plants. Note: ${ }^{*}, * *, * * *$ indicate significant at $0.01<P<0.05,0.001<P<0.01$, and $0<P<0.001$, respectively

of lead treatment, $57 \%(P=0.01), 66 \%(P=0.001)$ and $72 \%$ $(P=0.006)$ decrement was recorded in the plant height as the increased height was only 10,8 and 6 , respectively. $\mathrm{Pb}$-induced simulation of indole- 3 acetic acid (IAA) oxidation may be the primary cause of growth inhibition [1]. This result is amply supported by the reports of previous results indicating the inhibition of plant growth under the heavy metal stress [4, 24].

\subsection{Effect of Pb-induced stress on chlorophyll content}

A negative effect of heavy metal stress was observed in the chlorophyll content of the plant (Fig. 2). The concentration of chlorophyll content in the plant under controlled condition was $4.34 \mu \mathrm{g} / \mathrm{g}$ fresh weight. A reduction of $26 \%$ was observed in the chlorophyll content after the treatment of plant with $50 \mathrm{ppm}$ of $\mathrm{Pb}$ condition as before the treatment, the chlorophyll content was $3.30 \mu \mathrm{g} / \mathrm{g}$ fresh weight. The reduction reached up to $2.66 \mu \mathrm{g} / \mathrm{g}$ fresh weight which was $40 \%(P=0.02)$ lower when the concentration of $\mathrm{Pb}$ contamination was $100 \mathrm{ppm}$. Following the pattern, the significant reduction of about 1.8-fold $(P=0.009), 2.3$-fold $(P=0.006)$ and 3.4-fold $(P=0.003)$ was recorded when the extent of contamination was increased up to $150 \mathrm{ppm}, 200 \mathrm{ppm}$ and $250 \mathrm{ppm}$ as the concentration of chlorophyll content was $2.45 \mu \mathrm{g} / \mathrm{g}$ fresh weight, $1.89 \mu \mathrm{g} / \mathrm{g}$ fresh weight and $1.29 \mu \mathrm{g} / \mathrm{g}$ fresh weight, respectively. It was recorded to be directly affected in terms of heavy reduction which may be due to replacement of key nutrients ( $\mathrm{Mg}$, Fe and $\mathrm{Cu}$ ) by $\mathrm{Pb}$ which ultimately result in several consequences as disorganization and structural distortion of chloroplast, inhibition in the synthesis of chlorophyll as well as diminution in the amount of thylakoids and grana [4, 25]. Effect of heavy metal contamination on the chlorophyll content of the plant has also been reported earlier in sunflower [26] and almond [27], strawberry [28], spinach [29] and mungbean [20].

\subsection{Effect of $\mathrm{Pb}$-induced stress condition on protein content}

Protein content also showed a similar trend of reduction on increasing the treatment of $\mathrm{Pb}$ concentration which indicates the negative correlation between protein content and the $\mathrm{Pb}$ concentration in plant. About $0.89 \mu \mathrm{g} / \mathrm{g}$ fresh weight of protein content was recorded in controlled condition, and it was the highest protein content in the plant as compared to the treated condition (Fig. 3). The content of protein was $0.79 \mu \mathrm{g} / \mathrm{g}$ fresh weight and $0.687 \mu \mathrm{g} / \mathrm{g}$ fresh weight, showing decrement of $11 \%$ and $23 \%$ when the treatment of $50 \mathrm{ppm}$ and $100 \mathrm{ppm}$ of $\mathrm{Pb}$

\section{SN Applied Sciences}




\section{Change in protein content}

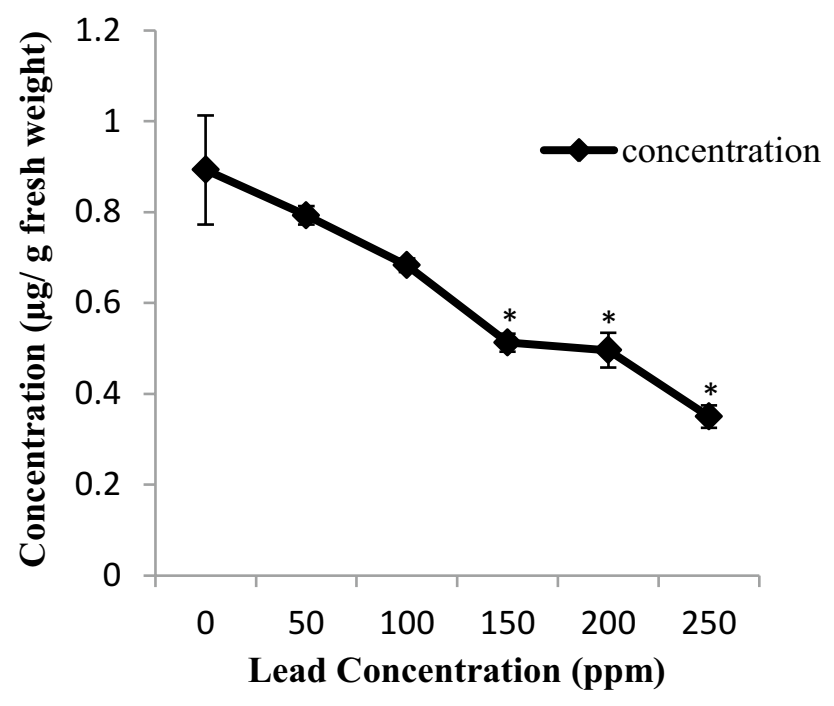

Fig. 3 Effect of different lead concentrations on protein content of $N$. arbor-tristis plants. Note: ${ }^{*},{ }^{* *},{ }^{* * *}$ indicate significant at $0.01<P<0.05,0.001<P<0.01$, and $0<P<0.001$, respectively

was given to the plants, respectively. A significant decrease of $43 \%(P=0.03), 44 \%(P=0.01)$ and $61 \%(P=0.01)$ was observed when the contamination of $\mathrm{Pb}$ increased up to $150 \mathrm{ppm}, 200 \mathrm{ppm}, 250 \mathrm{ppm}$ as the concentration of protein decreased up to $0.51 \mu \mathrm{g} / \mathrm{g}, 0.5 \mu \mathrm{g} / \mathrm{g}$ and $0.35 \mu \mathrm{g} / \mathrm{g}$ of fresh weight, respectively. These results coincide with the previous findings [30] in which a decrease in soluble protein content in Lemnapolyrrhiza L. was observed when grown on various treatments of lead and calcium. Different types of proteins synthesize under heavy metal stress resulting in an overall increase in protein content [31]. There may be some protease activity due to increased heavy metal stress conditions which is causing the decrease in protein content [32] as well as inducing lipid peroxidation and fragmentation of proteins due to toxic effects of reactive oxygen species which ultimately led to reduced protein content.

\subsection{Effect on SOD activity under Pb-induced stress}

A positive correlation was observed between SOD activity and increase in lead concentration (Fig. 4). After 90 days of lead treatment, the SOD activity of the plant treated with $50 \mathrm{ppm}$ and $100 \mathrm{ppm}$ of $\mathrm{Pb}$ condition was about $120 \mathrm{U} /$ mg protein and $158 \mathrm{U} / \mathrm{mg}$ protein which was approximately $40 \%$ and $85 \%(P=0.03)$ higher than the controlled condition, respectively. When the lead concentration was increased up to $150 \mathrm{ppm}, 200 \mathrm{ppm}$ and $250 \mathrm{ppm}$, significantly higher SOD activity was observed by its twofold increment $(P=0.01)$ as it reached up to $165 \mathrm{U} / \mathrm{mg}$ protein,
Change in SOD level

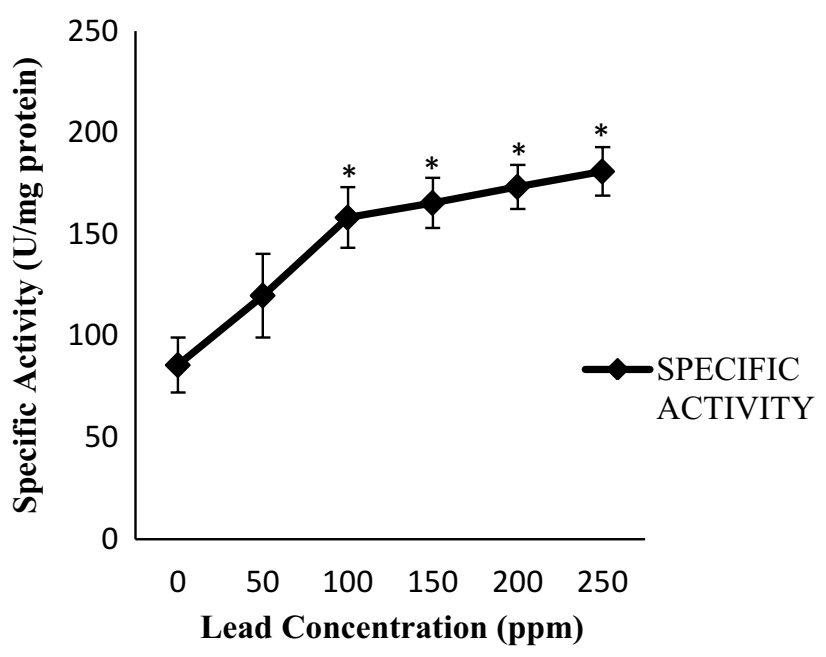

Fig. 4 Effect of different lead concentrations on SOD activity of $N$. arbor-tristis plants. Note: ${ }^{*}, * *, * * *$ indicate significant at $0.01<P<0.05,0.001<P<0.01$, and $0<P<0.001$, respectively

$173 \mathrm{U} / \mathrm{mg}$ protein and $180 \mathrm{U} / \mathrm{mg}$ protein, respectively, whereas the SOD activity of the plant under controlled condition was $86 \mathrm{U} / \mathrm{mg}$ protein. In plants, environmental adversities often led to the higher generation of ROS, and consequently, production of SOD has been proposed to be an important mechanism in plant stress tolerance [18] as it has an important role in ROS detoxification process as it converts $\mathrm{O}^{-2}$ to $\mathrm{H}_{2} \mathrm{O}_{2}$ [33]. Our findings are in agreement with these observations as the increased lead stress led to the significantly enhanced SOD activity confirming the oxidative stress tolerance.

\subsection{Effect on GPX level under Pd induced stress}

The $\mathrm{H}_{2} \mathrm{O}_{2}$ produced due to SOD activity is detoxified into $\mathrm{H}_{2} \mathrm{O}$ and $\mathrm{O}_{2}$ by other oxidative enzymes such as guaiacol peroxidase [33, 34]. Guaiacol peroxidase has role in several processes such as cell growth, auxin catabolism, lignifications as well as abiotic and biotic stress responses [35]. In this study, the plant under controlled condition was observed with a specific activity of $297 \mathrm{U} / \mathrm{mg}$ protein. After treating the plant with $50 \mathrm{ppm}$ of $\mathrm{Pb}$, the level of GPX increased up to $313 \mathrm{U} / \mathrm{mg}$ protein which was only $5 \%$, whereas after $100 \mathrm{ppm}$ and $150 \mathrm{ppm}$ of Pb treatment, the activity of GPX activity significantly increased up to $397 \mathrm{U} /$ $\mathrm{mg}$ protein and $408 \mathrm{U} / \mathrm{mg}$ protein which was about $33 \%$ $(P=0.005)$ and $37 \%(P=0.007)$ higher, respectively. The activity of GPX was significantly much higher in the plant grown in soil with 200 ppm and 250 ppm of Pb concentration as it reached up to the extent of $517 \mathrm{U} / \mathrm{mg}$ protein and $561 \mathrm{U} / \mathrm{mg}$ protein which was about $74 \%(P=0.001)$ and 
$89 \%(P=0.001)$ higher, respectively. A significant increase in GPX activity under lead-induced stress condition supports its essential role in detoxifying $\mathrm{H}_{2} \mathrm{O}_{2}$, produced due to enhanced SOD activity. The enhancement in the level of guaiacol peroxidase is considered as useful markers for environmental stress since their activity is affected by heavy metals and other environmental stress $[35,36]$ (Fig. 5).

\subsection{Effect on LPX level under Pb-induced stress}

Plasma membrane is composed of mainly lipids, and disruption in its integrity is also a response of heavy metal toxicity in plants. Malondialdehyde (MDA) is a product of lipid peroxidation which is also an indicator of oxidative stress after heavy metal stress, and it is correlated with the increase in concentration of heavy metal [37] that is why the extent of lipid peroxidation in the Pb-treated plants was observed through MDA assay. The specific activity of LPX of the plant under controlled condition was $12 \mathrm{U} / \mathrm{mg}$ proteins (Fig. 6). It was recorded that the lipid peroxidation increased up to $46 \%$ when the plant was treated with $50 \mathrm{ppm}$ of $\mathrm{Pb}$ as its specific activity was about $17 \mathrm{U} / \mathrm{mg}$ protein. The significant increase in the specific activity of LPX was recorded from the exogenous Pd treatment of $100 \mathrm{ppm}$ and above. The increment reached up to $64 \%$ $(P=0.01)$ when the treatment of plant increased about $100 \mathrm{ppm}$ of lead concentration as it raised the level of specific activity up to $19 \mathrm{U} / \mathrm{mg}$ protein. At $200 \mathrm{ppm}$ and $250 \mathrm{ppm}$ of lead concentration, the level of LPX activity was $36 \mathrm{U} / \mathrm{mg}$ protein and $40 \mathrm{U} / \mathrm{mg}$ protein showing

\section{Change in GPX level}

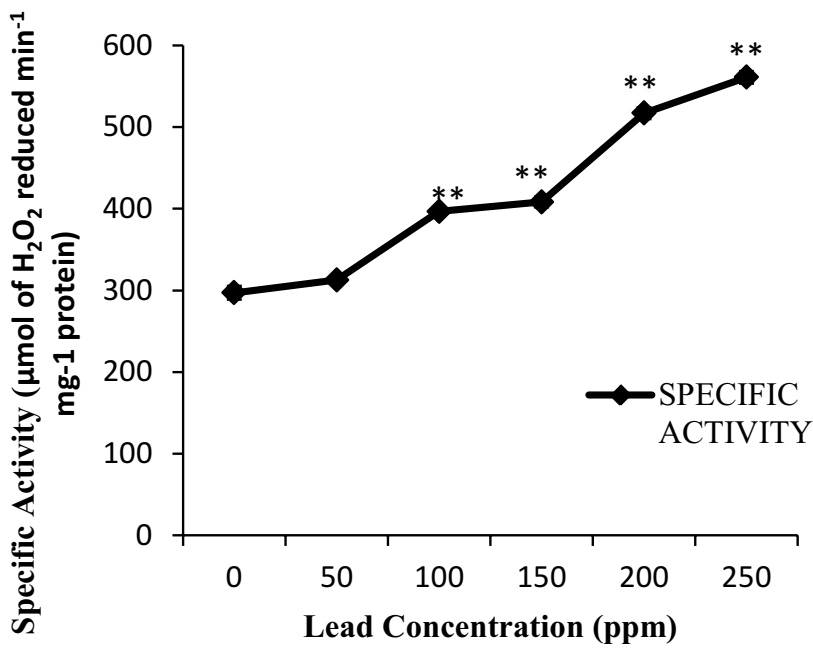

Fig. 5 Effect of different lead concentrations on guaiacol peroxidase activity of $N$. arbor-tristis plants. Note: ${ }^{*},{ }^{* *},{ }^{* * *}$ indicate significant at $0.01<P<0.05,0.001<P<0.01$, and $0<P<0.001$, respectively

\section{Change in LPX level}

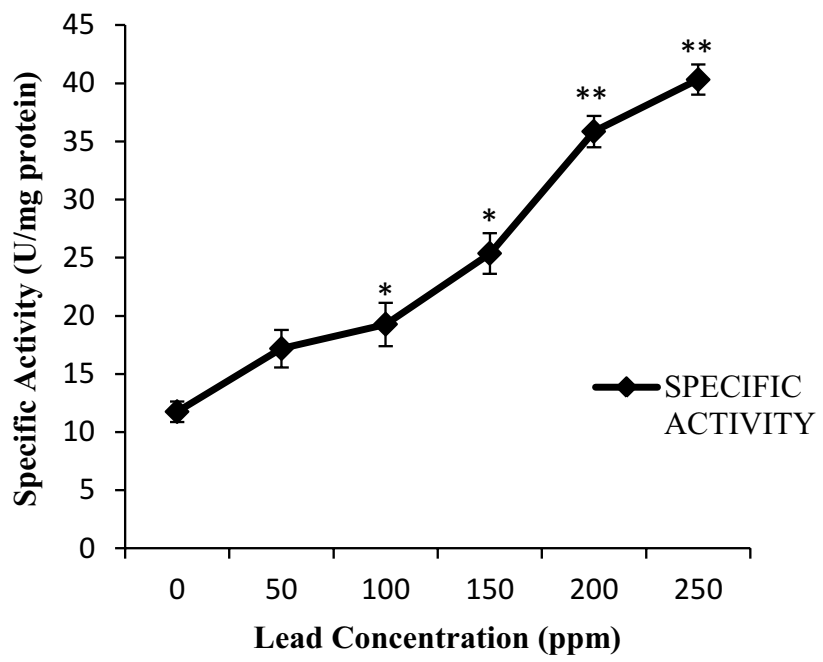

Fig. 6 Effect of different lead concentrations on lipid peroxidase activity of $N$. arbor-tristis plants. Note: ${ }^{*},{ }^{* *},{ }^{* * *}$ indicate significant at $0.01<P<0.05,0.001<P<0.01$, and $0<P<0.001$, respectively

approximate increase of threefold $(P=0.003)$ and 3.5fold $(P=0.002)$, respectively, that is highly significant. According to these findings, peroxidation of lipid greatly increases with the increasing concentration of $\mathrm{Pb}$ in plants as complex interaction between heavy metals and functional groups of membrane results in disruption of membrane integrity. More concentration of MDA symbolizes the higher level of lipid peroxidation which is a response of greater extent of heavy metal toxicity.

\subsection{Effect on NPTs level under Pb-induced stress}

Similar to other antioxidants, NPT level was also observed to be increased with the increasing lead concentration indicating a strong correlation between heavy metals toxicity and the level of NPTs [38]. The concentration of NPTs in the plant under controlled condition was about $7 \mathrm{nmol} / \mathrm{g}$ fresh weight. It increased up to $8 \mathrm{nmol} / \mathrm{g}$ fresh weight in the plant treated with $50 \mathrm{ppm}$ of $\mathrm{Pb}$ which was only about $20 \%$ higher but as the concentration of $\mathrm{Pb}$ increased to $100 \mathrm{ppm}$ and $150 \mathrm{ppm}$, the content of NPTs increased about twofold $(P=0.04)$ and 2.2 -fold $(P=0.04)$ significantly as the concentration was $13.8 \mathrm{nmol} / \mathrm{g}$ and $15.6 \mathrm{nmol} / \mathrm{g}$ fresh weight, respectively. The level of NPTs reached up to $20 \mathrm{nmol} / \mathrm{g}$ fresh weight showing a significant increment of about threefold $(P=0.04)$ in plants after the treatment of $250 \mathrm{ppm}$ of $\mathrm{Pb}$ (Fig. 7). These results are amply supported by the report [39] in which an increase was noticed in the NPT content in the leaves of $V$. myrtillus grown at a heavy metal polluted sites. High elevation in NPTs content was also reported in leaves of Silene vulgaris 


\section{Change in NPT level}

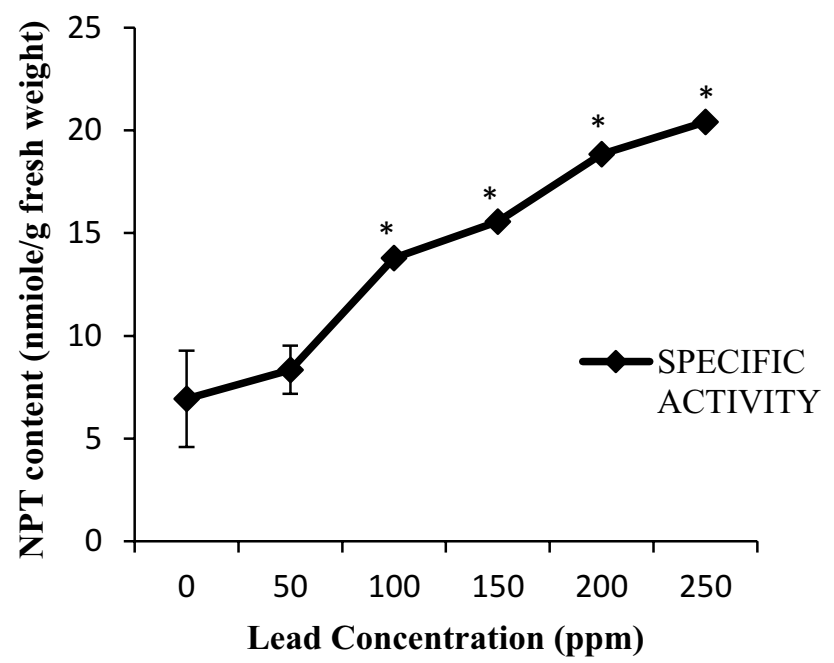

Fig. 7 Effect of different lead concentrations on NPT content of $N$. arbor-tristis plants. Note: ${ }^{*},{ }^{* *},{ }^{* * *}$ indicate significant at $0.01<P<0.05,0.001<P<0.01$, and $0<P<0.001$, respectively

populations on the substrate with the $\mathrm{Cd}$ and combination of metal ( $\mathrm{Zn}, \mathrm{Cd}$ and $\mathrm{Pb})[40]$.

\section{Conclusion}

The present study investigates the changes in height, antioxidant as well as physiochemical properties of $\mathrm{N}$. arbortristis plant due to exogenous lead treatment. Plants are widely used to alleviate the heavy metal stress from soil to improve the quality of soil as a bioremediator or phytoremediator. In this study, soil was treated with different concentrations of lead nitrate in order to observe its effect on the plant in terms of its morphological, biochemical and physiochemical properties. As per the obtained results, $N$. arbor-tristis is observed as an efficient $\mathrm{Pb}$ accumulator. The height of the plant was observed to be affected with increasing lead concentration of the soil. The levels of SOD, LPX, GPX and NPTs along with chlorophyll and protein contents were estimated in the present study. A significant increase was recorded in the concentration of SOD, LPX, GPX and NPTs content with the increasing concentration of $\mathrm{Pb}$ stress. Enhanced level of these antioxidants indicates that they have an essential role in coping up with the heavy metal stresses. Apart from this, Pb stress was observed to impart a negative effect on the content of chlorophyll and protein. It can be concluded through the significant increase in the level of antioxidants under exogenous lead treatment of $N$. arbor-tristis that the plant is capable for the remediation of heavy metal stress by virtue of good hyperaccumulation as well as its antioxidant properties. Planting of the Nyctanthes in contaminated soil with metals such as near industrial area may result in a possible approach for reducing soil pollution as well as its different parts have various medicinal properties which may be commercialized.

Acknowledgements This research was partially supported by Saaii College of Medical Science and technology, affiliated by Chattarpati Shahu Ji Maharaj University, Kanpur.

\section{Compliance with ethical standards}

Conflict of interest This research is not supported by any external funding. The mentioned authors merely hold the right of using the information of the generated data in this research. As well as there is not any issue with companies nor the conflict between any other institution and university.

\section{References}

1. Nagajyoti PC, Lee KD, Sreekanth TVM (2010) Heavy metals, occurrence and toxicity for plants: a review. Environ Chem Lett 8(3):199-216. https://doi.org/10.1007/s10311-010-0297-8

2. Michalak A (2006) Phenolic compounds and their antioxidant activity in plants growing under heavy metal stress. Pol J Environ Stud 15(4):523-530

3. Wieczorek J, Wieczorek Z, Bieniaszewski T (2005) Cadmium and lead content in cereal grains and soil from cropland adjacent to roadways. PJoES 14(4):535-540. https://doi.org/10.1007/s1064 6-010-0496-x

4. Lamhamdi M, El Galiou O, Bakrim A, Nóvoa-Muñoz JC, AriasEstévez M, Aarab A, Lafont R (2013) Effect of lead stress on mineral content and growth of wheat (Triticum aestivum) and spinach (Spinacia oleracea) seedlings. Saudi J Biol Sci 20(1):29-36. https://doi.org/10.1016/j.sjbs.2012.09.001

5. Raskin I, Smith RD, Salt DE (1997) Phytoremediation of metals: using plants to remove pollutants from the environment. Curr Opin Biotechnol 8(2):221-226

6. Khatun S, Ali MB, Hahn EJ, Paek KY (2008) Copper toxicity in Withania somnifera: growth and antioxidant enzymes responses of in vitro grown plants. Environ Exp Bot 64(3):279-285. https:// doi.org/10.1016/j.envexpbot.2008.02.004

7. Groppa MD, Tomaro ML, Benavides MP (2007) Polyamines and heavy metal stress: the antioxidant behavior of spermine in cadmium-and copper-treated wheat leaves. Biometals 20(2):185195. https://doi.org/10.1007/s10534-006-9026-y

8. Beladi M, Habibi D, Kashani A, Paknejad F, Nooralvandi T (2011) Phytoremediation of lead and copper by Sainfoin (Onobrychis vicifolia): role of antioxidant enzymes and biochemical biomarkers. Am Eurasian J Agric Environ Sci 10(3):440-449

9. Arnon DI (1949) Copper enzyme polyphenoloxides in isolated chloroplast in Beta vulgaris. Plant Physiol 24:1-15

10. Lowry OH, Rosebrough NJ, Farr AL, Randall RJ (1951) Protein measurement with the Folin phenol reagent. J Biol Chem 193(1):265-275

11. Beauchamp C, Fridovich I (1971) Superoxide dismutase: improved assays and an assay applicable to acrylamide gels. Anal Biochem 44(1):276-287. https://doi.org/10.1016/00032697(71)90370-8 
12. Egley GH, Paul RN, Vaughn KC, Duke SO (1983) Role of peroxidase in the development of water-impermeable seed coats in Sida spinosa L. Planta 157(3):224-232

13. Heath RL, Packer L (1968) Photoperoxidation in isolated chloroplasts: I. Kinetics and stoichiometry of fatty acid peroxidation. Arch Biochem Biophys 125(1):189-198

14. Nagalakshmi N, Prasad MNV (2001) Responses of glutathione cycle enzymes and glutathione metabolism to copper stress in Scenedesmus bijugatus. Plant Sci 160(2):291-299

15. Mithöfer A, Schulze B, Boland W (2004) Biotic and heavy metal stress response in plants: evidence for common signals. FEBS Lett 566(1-3):1-5

16. Bothe H (2011) Plants in heavy metal soils. In: Sherameti I, Varna A (eds) Detoxification of heavy metals. Springer, Berlin, pp 35-57

17. Yilmaz K, Akinci IE, Akinci S (2009) Effect of lead accumulation on growth and mineral composition of eggplant seedlings (Solarium melongena). New Zeal J Crop Hortic 37(3):189-199. https://doi.org/10.1080/01140670909510264

18. De Britto JA, Roshan Sebastian S, Sheeba Gracelin DH (2011) Effect of lead on malondialdehyde, superoxide dismutase, proline activity and chlorophyll content in Capsicum annum. Biores Bull 5:357-362

19. Singh G, Agnihotri RK, Reshma RS, Ahmad M (2012) Effect of lead and nickel toxicity on chlorophyll and proline content of Urd (Vigna mungo L.) seedlings. Int J Plant Physiol Biochem 4(6):136-141. https://doi.org/10.5897/ijppb12.005

20. Deshna D, Bafna A (2013) Effect of lead stress on chlorophyll content, malondialdehyde and peroxidase activity in seedlings of mung bean (Vigna radiata). Int J Res Chem Environ 3:20-25

21. Gubrelay U, Agnihotri RK, Singh G, Kaur R, Sharma R (2013) Effect of heavy metal $\mathrm{Cd}$ on some physiological and biochemical parameters of barley (Hordeum vulgare L.). Int J Agri Crop Sci 5(22):2743

22. Metwali, Gowayed SM, Al-Maghrabi OA, Mosleh YY (2013) Evaluation of toxic effect of copper and cadmium on growth, physiological traits and protein profile of wheat (Triticum aestivium L.), maize (Zea mays L.) and sorghum (Sorghum bicolor L.). World Appl Sci J 21(3):301-304

23. Siddiqui ZS (2013) Effects of double stress on antioxidant enzyme activity in Vigna radiata (L.). Acta Bot Croat 72(1):145156. https://doi.org/10.2478/v10184-012-0011-y

24. Zhang F, Wan X, Zheng Y, Sun L, Chen Q, Zhu X, Guo Y, Liu M (2014) Effects of nitrogen on the activity of antioxidant enzymes and gene expression in leaves of Populus plants subjected to cadmium stress. J Plant Interact 9(1):599-609. https://doi. org/10.1080/17429145.2013.879676

25. Akinci IE, Akinci S, Yilmaz K (2010) Response of tomato (Solanum lycopersicum L.) to lead toxicity: growth, element uptake, chlorophyll and water content. Afr J Agric Res 5(6):416-423. https:// doi.org/10.5897/ajar10

26. Zengin FK, Munzuroglu O (2006) Toxic effects of cadmium $\left(\mathrm{Cd}^{++}\right)$on metabolism of sunflower (Helianthus annuus L.) seedlings. Acta Agric Scand Sect B 56(3):224-229. https://doi. org/10.1080/0906471051003087

27. Nada E, Ferjani BA, Ali R, Bechir BR, Imed M, Makki B (2007) Cadmium-induced growth inhibition and alteration of biochemical parameters in almond seedlings grown in solution culture.
Acta Physiol Plant 29(1):57-62. https://doi.org/10.1007/s1173 8-006-0009-y

28. Muradoglu F, Gundogdu M, Ercisli S, Encu T, Balta F, Jaafar HZ, Zia-Ul-Haq M (2015) Cadmium toxicity affects chlorophyll a and $b$ content, antioxidant enzyme activities and mineral nutrient accumulation in strawberry. Biol Res 48(1):11. https://doi. org/10.1186/s40659-015-0001-3

29. Pandey N, Pathak GC, Pandey DK, Pandey R (2009) Heavy metals $\mathrm{Co}, \mathrm{Ni}, \mathrm{Cu}, \mathrm{Zn}$ and $\mathrm{Cd}$, produce oxidative damage and evoke differential antioxidant responses in spinach. Braz J Plant Physiol 21(2):103-111. https://doi.org/10.1590/s1677-0420200900 0200003

30. John R, Ahmad P, Gadgil K, Sharma S (2008) Effect of cadmium and lead on growth, biochemical parameters and uptake in Lemna polyrrhiza L. Plant Soil Environ 54(6):262

31. Shah K, Dubey RS (1997) Effect of cadmium on proline accumulation and ribonuclease activity in rice seedlings: role of proline as a possible enzyme protectant. Biol Plant 40(1):121-130. https ://doi.org/10.1023/a:1000956803911

32. Palma JM, Sandalio LM, Corpas FJ, Romero-Puertas MC, McCarthy I, Luis A (2002) Plant proteases, protein degradation, and oxidative stress: role of peroxisomes. Plant Physiol Biochem 40(6):521-530. https://doi.org/10.1016/s0981-9428(02)01404-3

33. Rastgoo L, Alemzadeh A (2011) Biochemical responses of Gouan ('Aeluropus littoralis') to heavy metals stress. Aust J Crop Sci 5(4):375

34. Wang C, Tian Y, Wang X, Geng J, Jiang J, Yu H, Wang C (2010) Lead-contaminated soil induced oxidative stress, defense response and its indicative biomarkers in roots of Vicia faba seedlings. Ecotoxicology 19(6):1130-1139. https://doi. org/10.1007/s10646-010-0496-x

35. Nadgórska-Socha A, Kafel A, Kandziora-Ciupa M, Gospodarek J, Zawisza-Raszka A (2013) Accumulation of heavy metals and antioxidant responses in Vicia faba plants grown on monometallic contaminated soil. Environ Sci Pollut Res 20(2):1124-1134. https://doi.org/10.1007/s11356-012-1191-7

36. Gao XH, Bedhomme M, Veyel D, Zaffagnini M, Lemaire SD (2009) Methods for analysis of protein glutathionylation and their application to photosynthetic organisms. Mol Plant 2(2):218235. https://doi.org/10.1093/mp/ssn072

37. Wu F, Zhang G, Dominy P (2003) Four barley genotypes respond differently to cadmium: lipid peroxidation and activities of antioxidant capacity. Environ Exp Bot 50(1):67-78. https://doi. org/10.1016/s0098-8472(02)00113-2

38. Kafel A, Nadgórska-Socha A, Gospodarek J, Babczyńska A, Skowronek M, Kandziora M, Rozpędek K (2010) The effects of Aphis fabae infestation on the antioxidant response and heavy metal content in field grown Philadelphus coronarius plants. Sci Total Environ 408(5):1111-1119. https://doi.org/10.1016/j.scito tenv.2009.11.013

39. Kandziora-Ciupa M, Ciepał R, Nadgórska-Socha A, Barczyk G (2013) A comparative study of heavy metal accumulation and antioxidant responses in Vaccinium myrtillus L. leaves in polluted and non-polluted areas. Environ Sci Pollut Res 20(7):4920-4932

40. Nadgórska-Socha A, Kandziora-Ciupa M, Ciepał R, Walasek K (2011) Effects of $\mathrm{Zn}, \mathrm{Cd}, \mathrm{Pb}$ on physiological response of Silene vulgaris plants from selected populations. Polish J Environ Stud 20(3):599-604 